\title{
Red tape, bribery and government favouritism: evidence from Europe
}

\author{
Mihály Fazekas ${ }^{1}$
}

Published online: 21 June 2017

C) The Author(s) 2017. This article is an open access publication

\begin{abstract}
Red tape has long been identified as a major cause of corruption, hence deregulation was advocated as an effective anticorruption tool, an advice which many country followed. However, we lack robust systematic evidence on whether deregulation actually lowers corruption. This is partially due to the difficulty of defining what is good regulation, but also to the lack of theoretical clarity about which type of corruption regulations impact on and to the deficient measurement of different types of corruption. In order to address the latter two gaps, we differentiate petty corruption from government favouritism and propose novel measurement of the latter by developing two objective proxy measures of favouritism in public procurement: single bidding in competitive markets and a composite score of tendering 'red flags'. Using publicly available official electronic records of over 2.5 million government contracts in 27 EU member states and two European Economic Area countries in 2009-2014, we directly operationalize a common definition of favouritism: unjustified restriction of access to public contracts to favour a certain bidder. Petty corruption is measured using business surveys while the extent of business regulation is measured by Doing Business expert assessment of precise regulatory costs. Using country-level panel regression analysis, we find that deregulation has a heterogeneous impact on both low and high level corruption. It is largely ineffective in tackling government favouritism, with business start-up deregulation even facilitating such corruption. Whereas deregulating the various channels through which governments and businesses interact (e.g. obtaining construction permits) often decreases the perception of bribery and petty corruption. Policy consequences are profound and point at a more targeted and context-dependent promotion of the deregulation agenda. Full public procurement database is available at http://digiwhist.eu/resources/data/.
\end{abstract}

Mihály Fazekas

mf436@cam.ac.uk

1 The Old Schools, University of Cambridge, Trinity Ln, Cambridge CB2 1TN, UK 


\section{Introduction}

Red tape or burdensome regulation has long been identified as a major cause for corruption, featuring as central in the earliest corruption literature already [1]. It has remained a central topic in both academic and policy discussions around the causes of and solutions to corruption. Intuitively, it is not hard to see why red tape may cause corruption: complicated, hard to understand and costly regulation increases both the potential for hiding corruption and the demand for corruptly avoiding such regulations. Deregulation therefore made it to the top of the agenda for fighting corruption and improving the business environment, spawning an impressive number of reforms across the globe: according to the World Bank Doing Business account of regulatory reforms, out of 189 countries, there were 46 reforming regulations around starting a business in each year between 2010 and 2015, but reforms were also very frequent in other regulatory areas falling between 11 and 33 per year [2].

However and quite unfortunately, we lack robust systematic evidence on whether deregulation actually lowers corruption and if yes how and under which conditions. Widely quoted reviews and cross-country studies only report correlations and find weak or conflicting evidence (i.e. some effects are significant, but some others insignificant) [3-5]. This is partially due to the difficulty of defining what is good regulation, i.e. regulation which best achieves public goals without creating excessive burden on the regulatee. However, the deficiency of evidence is also due to i) the lack of theoretical clarity about which type of corruption regulations impact on and ii) the imprecise measurement of different types of corruption. Different regulations regulate interactions between the state and businesses in various areas of state intervention from starting a business to enforcing contracts, implying different actors, types of transactions, and potential costs and benefits of the transaction. At a most basic level, two forms of corruption may be influenced differentially by business regulations: on the one hand, petty corruption or bribery arising directly at the point of interaction between agents of the state and businesses; on the other hand, government favouritism arising on a more systemic scale influencing the allocation of public resources more broadly. Importantly, these two types of corruption may or may not be correlated [6]. Measuring petty corruption or bribery has a long tradition which predominantly uses surveys of businesses or users of public services which while certainly having its limitations, can elicit information on a transaction the respondent can directly observe and recognise as corruption. However, measuring government favouritism has been a lot more challenging due to the subtle forms it can take and the wider populations' lack of direct experience with it [7].

We set out to answer the research question whether decreasing business regulatory burden decreases corruption in Europe. In order to address the gaps in the prior literature on this question, this article theoretically as well as empirically delineates petty corruption and government favouritism as well as precisely defines and quantitatively assesses the impact mechanisms different types of regulatory burdens have on them separately.

The contribution of this article is threefold: first, it develops a more nuanced theory about the relationship between business regulations and different types of corruption directly reflecting on the long-held view that corruption is far from a unitary phenomenon. It points out that regulating the low-level transactions between businesses and bureaucrats has very different effects on bribery in those very transactions than on government favouritism which is typically more systemic and takes place through 
sophisticated intermediaries such as offshore shell companies. Second, it develops two novel and innovative objective proxy measures of favouritism in government contracting: single bidding in competitive markets and a composite score of tendering 'red flags'. Using publicly available official electronic records of over 2.5 million government contracts in $27 \mathrm{EU}$ member states and European Economic Area countries in 2009-2014, it directly operationalizes a common definition of favouritism: unjustified restriction of access to public contracts to favour a certain bidder. Third, this article provides systematic quantitative evidence on the impacts of deregulation on low as well as high level corruption in a developed and generally well-governed region: Europe. The empirical findings caution against treating deregulation as panacea against corruption, especially against government favouritism, but also against petty corruption, albeit measurement issues may blur the clarity of findings in the latter respect. The empirical results also suggest that there may be a tension between fighting low versus high level corruption through deregulation.

\section{Theoretical frame}

First, we define the main theoretical concepts which are used in the analysis, most importantly low and high level corruption and business regulation; second, we outline the hypothesized causal mechanisms between types of business regulation and different corruption forms.

\section{Definitions}

Corruption is a diverse phenomenon touching on various government activities and actors, as well as achieving varying degrees of organizational sophistication and cohesion [8]. From the perspective of our research questions, a key distinction lies between low-level or petty corruption and high-level corruption or favouritism both of which relates to misusing public position and resources in one way or another (i.e. we exclude private to private corruption).

Petty corruption which is often equated with bribery has been the underlying corruption concept in many if not most corruption studies, it is most closely associated with the definition "the misuse of public office for private gain" [9]. This definition clearly sets out that corruption is an activity undertaken by those holding public office and implicitly implies that codes of conduct for public officials are well-defined along with an established separation between the public and private spheres. Furthermore, the scholarship based on this definition predominantly understood corruption within a bureaucratic context and equated corruption with bribery of public officials. Crucially, such low level corruption is conducted by street level bureaucrats directly discharging public duties and providing public services such as issuing permits or collecting taxes. In such situations, the corrupt exchange is typically done among individuals acting in their own best interests under the constraints of institutional and moral conditions, but typically without sophisticated corrupt organisations or networks supporting their acts. In a way, such corruption is close to a facilitator of a market exchange ([10], Chapter 2).

High level corruption or government favouritism arises in a rather different context than petty corruption. It typically characterises situations where a public positions entail 
a high degree of discretion such as members of parliament or government purchasing officers [11]. Political officeholders with considerable discretion as well as extensive powers may design institutions and rules specifically with the purpose of conducting corruption where low-level bureaucrats following the set rules would actually implement corrupt decisions in a corruption-free manner [7]. Hence, a broader definition of corruption better captures this kind of corruption invoking principles of impartiality, ethical universalism, and open access to public resources [12-14]: corruption is understood as a deliberate deviation from the norm of ethical universalism in order to benefit a particular group or individual in the exercise of public authority. Government favouritism is barely conducted by individuals pursuing their own goals, rather individuals form loser or denser coalitions or networks which are capable of collective action by monitoring and punishing its members.

Similar to corruption, defining government regulation of businesses is challenging as it takes diverse forms in different contexts. In order to keep the discussion tractable, we only concentrate on the types of business regulations captured by the World Bank's Doing Business methodology which brings about the benefit of tieing theory and measurement closely and also to rely on a well-defined and widely used framework [2]. Business regulations determine how businesses and their owners should behave to perform essential tasks throughout the life-cycle of a company imposing financial costs, time requirements, and bureaucratic procedures to follow (i.e. money, time, and number of procedures are key concepts for measurement). While this approach understands business regulations in a rather narrow sense and it certainly has limitations, it covers the whole spectrum of key business activities from starting to ending the life of a company. By and large, such regulations determine i) the creation and dissolution of a company; ii) ordinary interactions between private and public entities such as paying taxes; and iii) ordinary interactions between private entities such as getting credit from a bank. The latter type of regulations are included in the empirical analysis for the sake of completeness, but because they do not typically involve public actors as parties to the transactions they don't fall under any of the corruption definitions set out above, even though we are acutely aware of the severity and destructive effects of private-to-private corruption. ${ }^{1}$

\section{Mechanisms}

Given that petty and grand corruption each have different characteristics, actors, and organisational forms, the impact of business regulations on them is expected to be different too.

As to petty corruption, cumbersome, complicated and hard-to understand regulations create both incentives to give a bribe and opportunities to accept a bribe as acknowledged by a wide range of authors $[3,5,15,16]$. On the one hand, burdensome regulation imposes high costs on firms in terms of uncertainty, time spent on dealing with regulations and monetary costs of the procedures. Decreasing such costs acts as an incentive to pay a bribe to shortcut red tape. Deregulation and simplification decreases

\footnotetext{
${ }^{1}$ The reader might note that getting electricity is often also an interaction between two private entities. However, because in many countries energy suppliers are often either state owned or tightly regulated by governments; and because electricity supply is a political issue to considerable degree, we consider it a private to public interaction.
} 
such costs hence the incentives to give a bribe [17]. On the other hand, complicated and convoluted regulations allow street-level bureaucrats to create uncertainty and apply discretion hence the opportunity to ask for bribes arises. Deregulation and simplification limits street-level bureaucrat's discretion and reduces regulatory uncertainty which in turn can decrease the incidence of bribery [18]. Moreover, deregulation and simplification can also increase the competition among administrators offering public services hence decreasing corruption [4]. These three impact mechanisms separately as well as jointly imply that deregulation would decrease petty corruption among public officials across all measured regulatory areas (Table 1).

As to government favouritism, the literature is rather scant and effects are much more ambiguous. Given the much higher organisational sophistication of government favouritism and the deliberate use of state hierarchy and public administration for the purposes of rent extraction, we can identify three major impact channels. First, government favouritism relies on private companies as vehicles of rent extraction [19]. Hence, the regulation of the creation and cessation of corporations is central to government favouritism [20]. Given that complex corporate structures are conducive to hiding corruption, the easier it is to create companies the lower the cost of conducting government favouritism. Suspicious or illicit financial flows often signal that a company is corruptly used and hiding corrupt rents through irregular company dissolution can also underpin government favouritism. By implication, the more cumbersome, complex, and uncertain insolvency regulations are, the more easy it is to conduct complex corrupt deals. Second, the ambiguity of legal contracts is often exploited by corrupt networks to impose informal governance on their members [21]. Legal uncertainty and the weakness of judicial systems in efficiently enforcing contracts can facilitate corrupt deals [22]. Hence, the more straightforward, timely, and cheap it is to enforce contracts the more difficult it is to govern complex favouritistic networks. Third, regulations of ordinary transactions between street-level bureaucrats and firms have no direct bearing on government favouritism given that they represent essentially distinct areas of government activity. This point essentially restates the starting point of this article: low and high level corruption may or may not be correlated [6]. Nevertheless, regulating ordinary interactions between private and public entities such as paying

Table 1 Summary of theoretical expectations by business regulation and corruption types

\begin{tabular}{lll}
\hline Doing Business component & bribery & favouritism \\
\hline total regulatory burden & - & $0 /-$ \\
starting business & - & + \\
resolving insolvency & - & - \\
enforcing contracts & - & - \\
registering property & - & $+/-$ \\
getting electricity & - & $+/-$ \\
construction permits & - & $+/-$ \\
trade & - & $+/-$ \\
paying taxes & - & $+/-$ \\
getting credit & 0 & 0 \\
protecting investors & 0 & 0
\end{tabular}


taxes can indirectly influence government favouritism through bribery. This is because low-level corruption can contribute to maintaining larger favoritistic networks. Corrupt elites may find it beneficial to allow low-level bureaucrats to extract rents from their daily transactions in order to keep them aligned with the dominant corrupt coalition; in effect using bribery as way to increase their governing capacity and survival chances [23]. However, corrupt elites may also chose to limit low-level corruption arising during the interaction between street-level bureaucrats and businesses in order to maximize their own control over the state apparatus and distribution of corrupt rents. These two arguments suggest a two indirect impacts: i) where bribery is high, deregulation can lower government favouritism by decreasing the incidence of bribery hence weakening the favoritistic network itself; ii) where bribery is low, deregulation can increase government favouritism through decreasing bribery and strengthening the grip of a corrupt elite. Hence, the effect of deregulating ordinary state-business transactions is expected to be directly null, and indirectly either positive or negative depending on the amount of bribery present to start with.

In sum, the total combined effect of deregulation in all regulatory areas is negative on low level corruption and ambiguous on government favouritism. We summarize all the hypothesized effects below (Table 1).

\section{Data and indicators}

We bring together three different datasets: survey data on bribery in business transactions, public procurement data on government favouritism, and the World Bank's Doing Business data on business regulations. These datasets represent information on different levels, with the country-year level being the common level allowing to combine all of them. While ideally, the multi-level nature of the datasets would need to be taken into account, due to deficiencies in measurement precision, we will only consider country-year observations.

\section{Measuring petty corruption}

Petty corruption and bribery are measured using business executive surveys of i) the World Economic Forum's Global Competitiveness Report, and ii) the Institute for Management Development's World Competitiveness Yearbook. Both surveys ask business executives, predominantly those working for large international corporations [24, 25].

The World Economic Forum (WEF) variable used is "Irregular payments and bribes" (variable number 1.05) calculated as the average score across the five components of the following Executive Opinion Survey questions:

"In your country, how common is it for firms to make undocumented extra payments or bribes connected with (a) imports and exports; (b) public utilities; (c) annual tax payments; (d) awarding of public contracts and licenses; (e) obtaining favorable judicial decisions?"

This data is available for all 29 countries in our sample, however, unfortunately, the first year the survey question was asked is 2010 leaving the analysis using this variable one year shorter. 
The Institute for Management Development (IMD) variable is "Bribing and corruption exist in the economy" containing responses to the very similar survey question:

\section{"Bribing and corruption: Exist or do not exist."}

This variable is available for the full time period and all 29 countries with the only caveat that a few years' observations are missing for Iceland and Latvia before 2013.

Both bribery variables were scaled to fall between 0 and 100 with 0 reflecting minimum perceptions of petty corruption and bribery and 100 maximal perceptions (note that this scaling is different broth from the original and the rescaling applied by the WGI-Control of Corruption indicator methodology) (Table 2). While these indicators only ask about general perceptions, the types of corrupt transactions are directly observable for respondents in their daily practices making responses reasonably precise. However, both surveys predominantly target large international businesses whose views may very much differ from domestic small and medium enterprises' views on corruption, for example because foreign investors often receive special treatment by governments when acquiring land or setting up a company.

Neither of the two measures of petty corruption fit perfectly our theoretical concept, unfortunately. The WEF indicator also asks about making undocumented extra payments or bribes connected with the awarding of public contracts and licenses, making it partially overlapping with the below measure of government favouritism in public procurement. While this overlap is only less than a fifth of the total score, it probably contributes to its moderately strong correlation with measures of government favouritism (linear correlation coefficients of $0.45-0.67)$. The IMD indicator is very generic in its wording leaving us to wonder how exactly respondents interpret it and to what degree they also incorporate

Table 2 Descriptive statistics of dependent and key independent variables used in the analysis, 2009-2015, Europe

\begin{tabular}{|c|c|c|c|c|c|}
\hline Variable & Obs & Mean & Std. Dev. & Min & Max \\
\hline IMD: Bribing and corruption & 219 & 51.70 & 26.34 & 7.12 & 97.78 \\
\hline WEF: Irregular payments \& bribes & 174 & 30.99 & 16.47 & 5.14 & 60.77 \\
\hline single bidder $\%$ & 170 & 17.57 & 11.94 & 2.13 & 60.36 \\
\hline Corruption Risk Index (CRI) & 170 & 24.33 & 8.82 & 9.21 & 60.81 \\
\hline total DB score & 203 & 72.91 & 6.79 & 55.49 & 85.79 \\
\hline starting business & 231 & 87.55 & 6.42 & 60.85 & 96.27 \\
\hline resolving insolvency & 231 & 65.50 & 21.43 & 22.48 & 97.80 \\
\hline enforcing contracts & 231 & 68.93 & 10.19 & 38.21 & 86.04 \\
\hline registering property & 231 & 73.40 & 14.16 & 34.16 & 94.12 \\
\hline getting electricity & 174 & 76.03 & 12.55 & 45.09 & 98.37 \\
\hline getting construction permits & 231 & 71.02 & 12.90 & 13.53 & 91.59 \\
\hline trading across borders & 231 & 83.89 & 5.88 & 70.54 & 93.43 \\
\hline paying taxes & 231 & 77.44 & 10.86 & 48.93 & 95.28 \\
\hline getting credit & 231 & 66.82 & 16.78 & 15.00 & 100.00 \\
\hline protecting investors & 231 & 56.93 & 11.14 & 30.00 & 83.33 \\
\hline
\end{tabular}


notions of government favouritism into their answers. This ambiguity and potential overlap are likely to contribute to the IMD indicator's moderately strong correlation with measures of government favouritism (linear correlation coefficients of 0.62-0.67). In spite of these partial overlaps, the selected measures of petty corruption are the best available for our country and period sample deemed of sufficient quality for the analysis.

\section{Measuring government favouritism}

Measuring government favouritism is much more problematic and so far there have been only very few examples of reliable cross-country measurements [7]. One particular challenge is that survey respondents typically have little direct experience with it as it can take subtle forms and manifest in decisions comprehensible only to experts. In order to overcome these challenges, we look into only one large area of government spending: public procurement or government contracting where benchmarks of open and fair competition are well established along with regulations against undue influence and conflict of interest. By implication, our general definition of government favouritism translates into a directly measurable concept in public procurement: the aim of government favouritism is to steer the contract to the favoured bidder without detection in a recurrent and organised fashion [26, 27]. This requires at least two violations of principles of impartial distribution of public resources: 1) avoiding competition, by for example using unjustified sole sourcing or direct contract awards; and 2) favouring a certain bidder, by for example tailoring specifications, or sharing inside information. Such restricted and unfair access then translates into higher prices, lower quality and quantity in order to generate corruption rents.

While public procurement is only one area where government favouritism can manifest, it is a comparatively large domain of government activities (accounting for roughly one third of government spending according to OECD) and represents a distinct set of motivations for high-level corruption: considerable discretion in project design and purchasing decisions and concentration of public money in a few high-value decisions (e.g. airport construction). By implication, favouritism in public procurement is likely to be visible if there is such corruption at the top of government allowing us to take it as a proxy for government favouritism more generally. We argue that high-level, institutionalised forms of corruption typically take control of an array of government activities, including public contracting hence, measuring corruption in one area is indicative of the same type of corruption in other areas of government activities. However, the caveat applies that measured public procurement corruption only provides a lower bound estimate of government favouritism more broadly. This is because on the one hand our measurement instruments deliver only a lower bound estimate for public procurement corruption itself, and on the other hand because even when public procurement is clean, other areas such as law making, selling public property, or allocating public subsidies may well be corrupt.

For the purposes of measurement we measure government favouritism in public procurement using micro-level data describing individual procurement tenders and contracts. We obtain data using automated web crawling and text mining algorithms directly from the official government websites. Our public procurement database derives from public procurement announcements in 2009-2015 as appearing in the so-called Tenders Electronic Daily (TED), which is the online version of the 'Supplement to the Official Journal of the EU', dedicated to European public procurement [28]. The data represent a complete database of all public procurement procedures conducted under the EU Public 
Procurement Directive by EU member states, countries in the European Economic Area, or the European Commission regardless of the funding source (e.g. national, EU funded). The regulation of government contracting in WTO member states including the EU suggest that similar datasets can be constructed globally. The database was released by the European Commission - DG GROWTH ${ }^{2}$ which also has conducted some data quality checks and enhancements. TED contains variables appearing in 1) calls for tenders, and 2) contract award notices. All the countries' public procurement legislation is within the framework of the EU Public Procurement Directives, hence the national datasets are therefore directly comparable [29]. The source TED database contains over 3 million contracts. The public procurement database used in this analysis, including corruption risk indicators can be downloaded from http://digiwhist.eu/resources/data/.

The measures of government favouritism put forward below only proxy such behaviours capturing the risk of corruption rather than it actually occurring. The measurement instrument directly stems from the above definition of corruption in public procurement and follow work of the authors elsewhere discussed extensively both single country and cross-country analyses [30-32]. We understand corruption risk indicators as metrics ranging between 0 and 100 where higher values indicate higher risk of corruption or government favouritism (Table 2). The measurement approach exploits the fact that for government favouritism to work, procurement contracts have to be awarded recurrently to companies belonging to the corrupt network. This can only be achieved if legally prescribed rules of competition and openness are circumvented. By implication, it is possible to identify the input side of the corruption process, that is fixing the procedural rules for limiting competition, and also the output side of corruption, that is signs of limited competition. By measuring the degree of unfair restriction of competition in public procurement, proxy indicators of corruption can be obtained.

First, the simplest and most conservative indication of restricted competition in line with the above definition is when only one bid is submitted to a tender on an otherwise competitive market (output side). While single bidding might also reflect non-corrupt behaviour such as contract renewal, its widespread presence over longer periods across many procuring bodies is more likely to signal systematic deviations from competitive norms. Hence, the percentage of single-bidder contracts awarded with all the contracts is the most straightforward corruption proxy we use.

Second, a more complex indicator of corruption also incorporates characteristics of the tendering process that are in the hands of public officials who conduct the tender and suggests deliberate competition restriction (input side) [33]. This composite indicator, which we call the Corruption Risk Index (CRI), represents the risk of corrupt contract award in public procurement, and is constructed as a simple weighted average of individual red flags. Based on qualitative interviews of corruption in the public procurement process, a review of the literature [27, 34, 35], and regression analysis, we identified the components of the CRI in addition to single bidding:

1. A simple way to fix tenders is to avoid the publication of the call for tenders in the official public procurement journal as this would make it harder for competitors to prepare a bid. This is only considered in non-open procedures as in open procedures publication is mandatory [36].

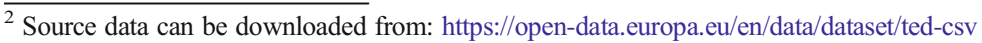


2. While open competition is relatively hard to avoid in some tendering procedure types such as open procedures, others such as accelerated negotiated or negotiated without competition procedures are by default much less competitive; hence, using less open and transparent procedure types can indicate the deliberate limitation of competition, that is corruption risks [37].

3. If the advertisement period, i.e. the number of days between publishing a tender and the submission deadline, is too short for preparing an adequate bid, especially for large tenders considered in this study, it can serve corrupt purposes; whereby the issuer informally tells the well-connected company about the opportunity well ahead [38].

4. Different types of evaluation criteria are prone to manipulation to different degrees, subjective, hard-to-quantify criteria often accompany rigged assessment procedures as it creates room for discretion and limits accountability mechanisms [34].

5. If the time used for deciding on the submitted bids is excessively short or lengthened by legal challenge, it can also signal corruption risks. Snap decisions on large value tenders may reflect premediated assessment, while legal challenge and the corresponding long decision period suggests outright violation of laws [39].

Regression analysis was used to identify 'red flags' which are most likely to signal corruption rather than any other phenomena such as low administrative capacity. For full details on these regressions see [40].

Each of the two corruption risk indicators have its pros and cons. They are both preferable over widely used perception indicators as they directly point at specific corruption risks reflecting actor behaviour as captured by objective data. The strength of the single bidder indicator is that it is very simple and straightforward to interpret. However, it is also more prone to gaming by corrupt actors due to its simplicity (e.g. faking competition by submitting another, deliberately losing bid). The strength of the composite indicator approach (CRI) is that while individual strategies of corruption may change as the environment changes, they are likely to be replaced by other techniques. Therefore, the composite indicator is a more robust proxy of corruption over time than a single variable approach. In an international comparative perspective, a further strength of CRI is that it balances national specificities with international comparability by allowing for the exact list and formulation of the components to vary reflecting differences in local market conditions and corrupt practices (e.g. in some countries short advertisement periods are rare and are not systematically associated with a heightened probability of single bidding, hence the national CRI does not include this component). Hence, CRI in an international comparative perspective captures the frequency of likely corrupt behaviours in each context while abstracting from the specific procedural details. The main weakness of CRI is that it can only capture a subset of corruption strategies used, hence it may be a biased measure of corruption.

It can be argued that both corruption proxies capture the simplest and most straightforward signs of competition restriction, hence they miss out on sophisticated types of corruption such as corruption combined with inter-bidder collusion. This is problematic in as much as corruption is frequently combined with collusive bidding as for example extensive market transparency and high entry costs encourage cartels [41, 42].

As both corruption proxies can be associated with non-corrupt phenomena, we look at external validity tests to demonstrate that they are more often linked to government 
favouritism than other behaviours. The simplest such test is comparing objective corruption proxies with corruption perceptions which provides a strong support to our interpretation of the data, as for example business executives perceptions of government favouritism in awarding public contracts is strongly correlated with both objective proxies: linear correlation coefficients range between $0.6-0.7$ for a sample of European countries [40]. As country-level perceptions might be biased, we conduct micro-level validity tests using other objective corruption risk proxies. One such widely accepted proxy is the registration of companies in tax haven jurisdictions such as Panama [43]. Hence, it is expected that a contract represents a higher corruption risk if it is awarded to a company registered in a tax haven as its secrecy allows for hiding illicit money flows. In line with our expectations, all across the EU27 plus Norway there is a marked and significant difference in the percentage of single bidder contracts won by foreign companies registered in tax havens versus those which are not: 0.28 versus 0.26 ; similarly for CRI: 0.34 versus 0.31 respectively $\left(\mathrm{N}_{\text {contract }}=28,642\right)$. For further validity tests and validating applications, see [30, 40, 44].

\section{Measuring business regulation}

For measuring different aspects of business regulation in each of the 29 European countries in our sample over time, we use the World Bank's Doing Business indicators [2]. They provide quantitative measures of regulations for domestic small and mediumsize enterprises in terms of

- starting a business,

- resolving insolvency,

- enforcing contracts,

- registering property,

- getting electricity,

- getting construction permits,

- trading across borders,

- paying taxes,

- getting credit, and

- protecting investors.

Regulation in these 10 areas is measured using standardized case studies capturing typical cases arising throughout the life-cycle of companies rather than soliciting general perceptions. This makes indicators strictly speaking internationally comparable at the expense of very narrow focus of the data. Data comes from 2 sources: The first come from readings of laws and regulations by both the local expert respondents and Doing Business. The second are time-and-motion indicators that measure the efficiency in achieving a regulatory goal (such as granting the legal identity of a business). Regulatory costs are measured in terms of i) monetary costs such as official fee schedule for obtaining a license; ii) amount of time needed to complete a procedure such as number of days needed for registering a company; and iii) number of procedures needed to achieve a regulatory outcome such as obtaining a permit. Where sufficient detail is provided, official documentation is used, in other cases estimates are based on the informed judgment of expert respondents who routinely administer or advise on the relevant regulations. 
In order to keep the number of variables pertaining to business regulations tractable, we used a summary score for each of the 10 regulatory areas as well as for the total business regulatory environment. Summary scores represent the distance to frontier (DTF) scores as officially calculated by the Doing Business team [45]. It involves two main steps: first, individual component indicators are normalized to a common unit where each of the 36 component indicators y (except for the total tax rate) is rescaled using the linear transformation (worst $-y$ ) / (worst - frontier). In this formulation the frontier represents the best performance on the indicator across all economies since 2005. Both the best performance and the worst performance are established every five years based on the Doing Business data for the year in which they are established, and remain at that level for the five years regardless of any changes in data in interim years. Thus, DTF scores are highly standardized for the period under investigation in this study (2009-2015) reflecting changes in the countries' regulations rather than the frontier itself. Such formulation of DTF scores imply that 0 means the most burdensome regulation and 100 the least burdensome or best regulation (Table 2).

\section{Results}

In order to test the effects of deregulation on low and high level corruption, we conduct a series of panel data regressions in our 29 European countries between 2009 and 2015. In particular the following model is estimated:

$$
\operatorname{Corr}_{i, t}=\alpha_{i}+\beta \text { Regulation }_{i, t}+\beta X_{i, t}^{\prime}+\varepsilon_{i, t}
$$

Where Corr is a measure of corruption either petty or grand in country $i$ in year $t$, which will take two alternative forms for each type of corruption: for petty corruption it is either the World Economic Forum or Institute for Management Development survey scores; for government favouritism, it is either the average ratio of tenders for which only one bidder submitted an offer (Single Bidder), or the more comprehensive corruption risk measure also incorporating tendering red flags (CRI). The main explanatory variable that we put to test is Regulation, a continuous score reflecting the burden of complying with business regulations in country $i$ in year $t$, either as a total combined score for all regulatory areas or individual scores for each area. In addition, $X$ represents a vector of covariates that will differ by the type of estimation carried out, but in its fullest form include, per country $i$ and year $t$ : a measure of annual GDP growth, a measure of GDP per capita, a proxy measure of technological progress and citizen engagement capturing the number of internet users; a dummy for Eastern European countries and a final proxy measure capturing the level of industrial development of the economy by computing the value added of the industrial sector as a $\%$ of national GDP. All these covariates are in theoretical terms potential additional explanatory factors for corruption in a country [46]. Overlooking them could easily lead to omitted variable bias where changes in both the explanatory and dependent variable may be driven by these omitted aspects. Finally, $\varepsilon$ is the random error measure by country $i$ in year $t$.

The below panel regression results are split up according to the two main types of dependent variables (i.e. petty corruption and government favouritism) in order to clearly identify the effects of deregulation on each of them, while an additional set of regressions also investigate interactions between these two forms of corruption. 


\section{Deregulation and petty corruption}

Total Doing Business score has very small and insignificant impact on petty corruption in our fixed effects panel regression models (results using IMD: bribing and corruption as outcome variable are in Table 3; results using WEF irregular payments and bribery are in Table 6 in Appendix). This is contradicting our theoretical expectation which might be partially due to the low sensitivity to change of corruption perceptions at the country level or the relative remoteness of large international businesses from typical regulatory situations arising from SMEs. Among the hypothesized negative relationships between regulation in individual areas and petty corruption, 3 are in line with expectations (using the IMD outcome measure): registering property, getting electricity, and getting construction permits. By far, the strongest effect is attributed to getting electricity regulations, where moving a country's regulatory regime 1 percentage point closer to the frontier results in a 0.62 points lower perception of petty corruption among businessmen. Moving from the average European electricity regulation score of $76 \%$ to the best European score of $98.4 \%$ (Germany) would result in our model in about 14 points improvement in perceptions of petty corruption which would be equivalent to moving Poland (66 points) to the European average (52 points). While the other regulatory area-specific effects are insignificant, to our surprise regulations relating to trading across borders have a significant positive impact on corruption perceptions, that is increasing perceptions (using the IMD outcome measure), while the same relationship is significant negative using the WEF measure. These contradictory results, however, are most likely to be confounded by the low variance in the European sample due to the equalizing effect of the EU's and EEA's single market.

In line with our hypotheses, regulations of private-to-private business interactions have an insignificant effect on petty corruption in our models.

\section{Deregulation and government favouritism}

Total Doing Business score has very small and insignificant impact on government favouritism in our fixed and random effects panel regression models (results using single bidding as outcome variable are in Table 4; results using CRI are in Table 7 in Appendix). This is in line with our theoretical expectation reflecting the heterogeneous effect of different regulatory areas in composing the overall effect.

Among the hypothesized effects of regulations constraining government favouritism, all effects are in line with expectations being significant and of considerable size for regressions using single bidding as an outcome (effects are not always significant at the $5 \%$ level for CRI). The strongest effect is attributed to business startup regulations, where moving a country's regulatory regime 1 percentage point closer to the frontier economy results in a 0.5 percentage points higher single bidding share. Moving from the average European start-up regulation score of $88 \%$ to the best European score of 94\% (Belgium) would result in our model in about 3.3 percentage points higher single bidding share (more government favouritism) which would be equivalent to moving France (14\%) to the European average (17\%).

Among the hypothesized conditional relationship between regulations of daily interactions between businesses and governments and high level corruption, we find mixed empirical evidence for our hypotheses (both sets of regressions using single bidding and 


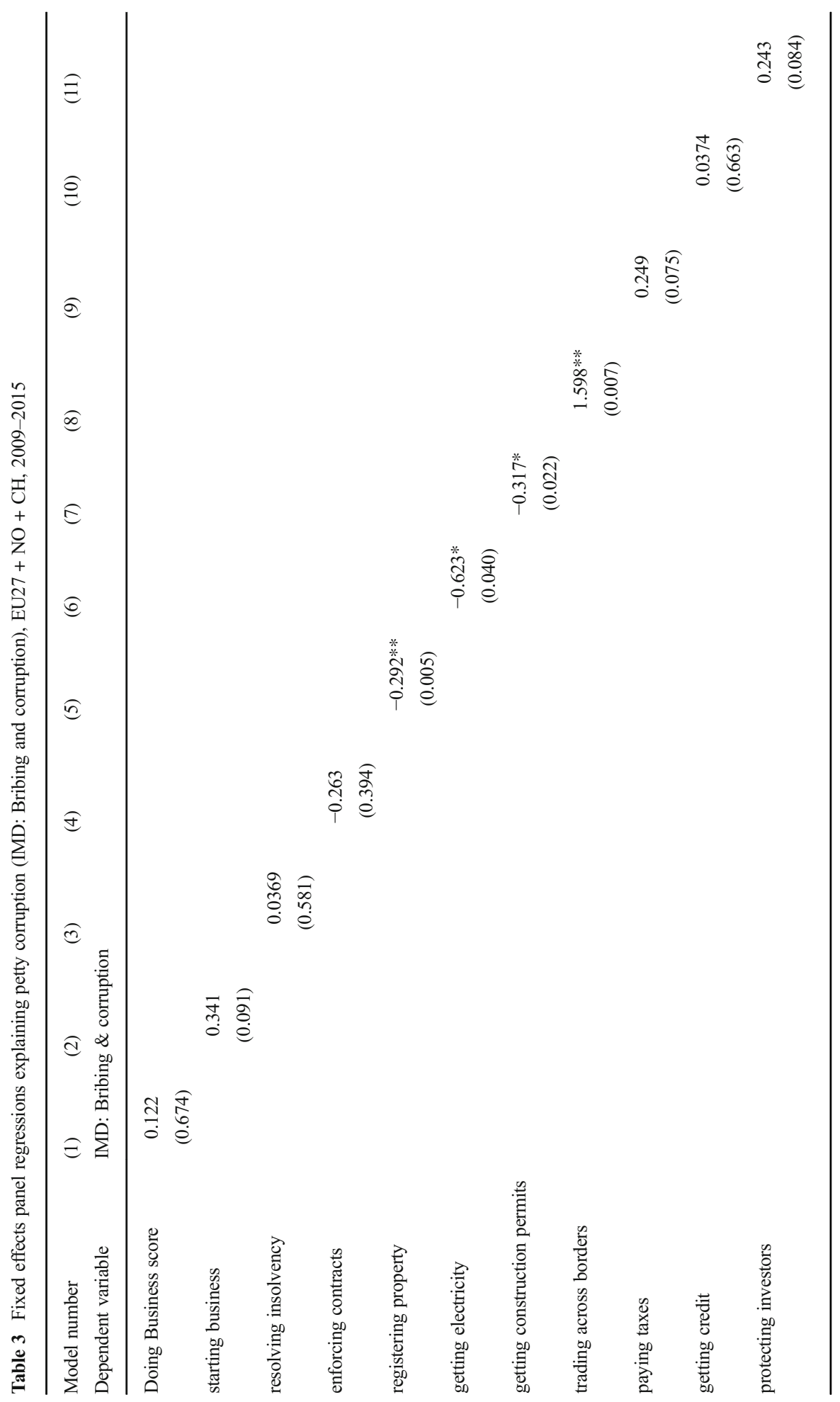




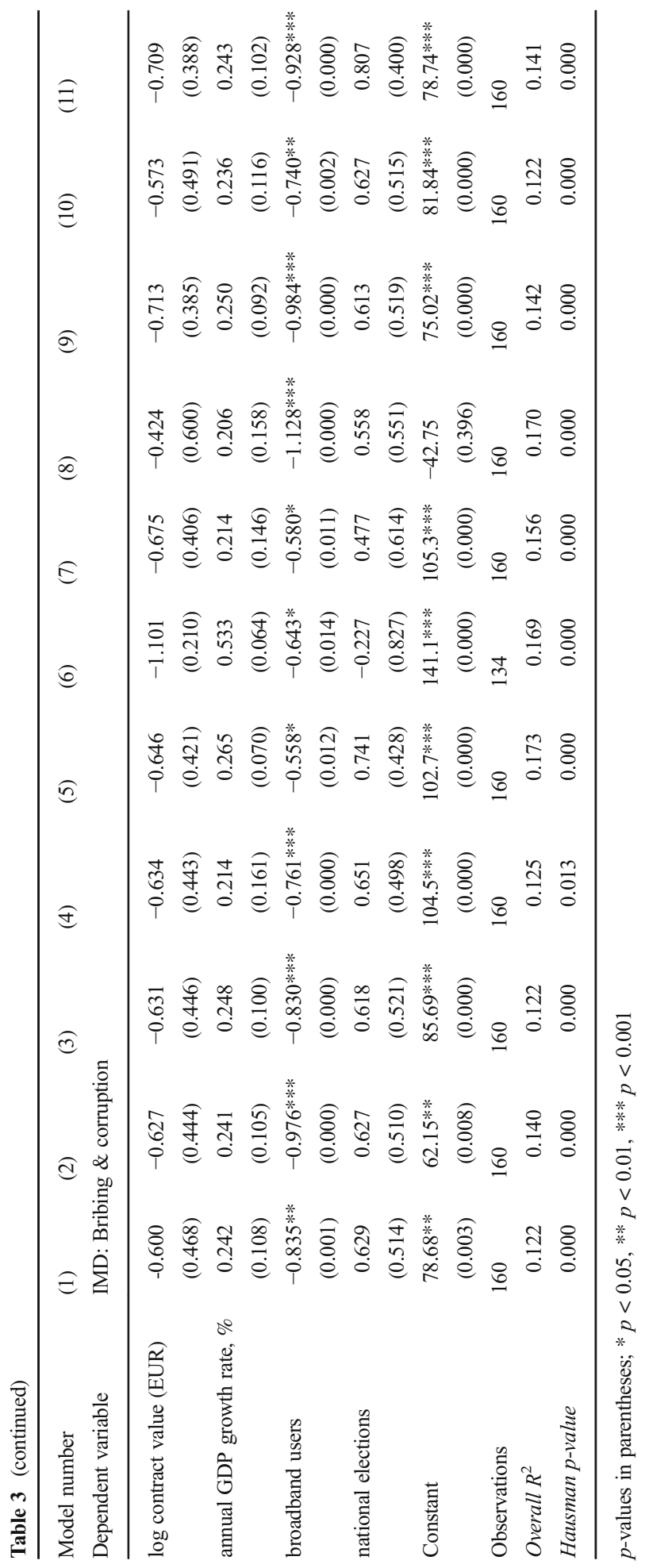




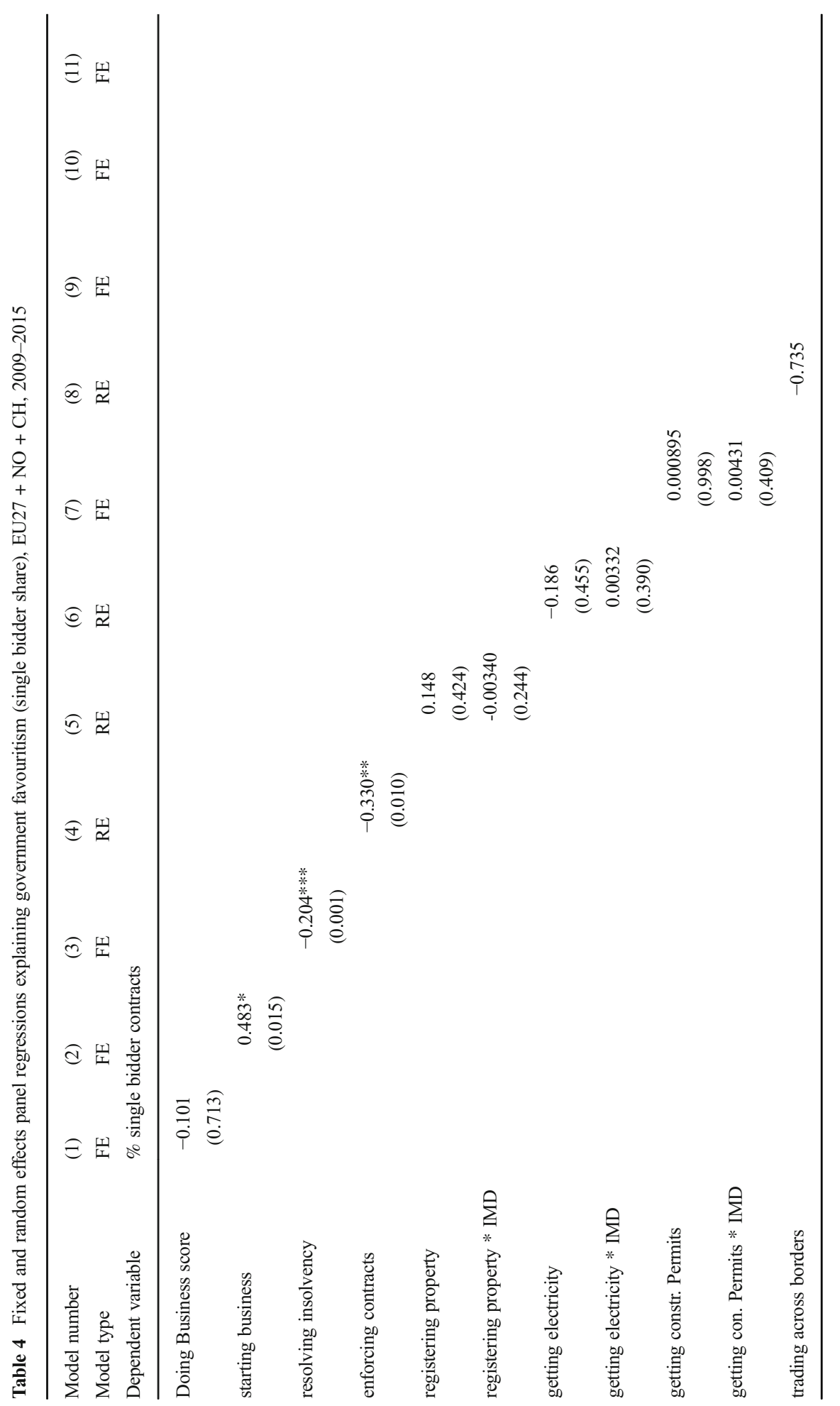




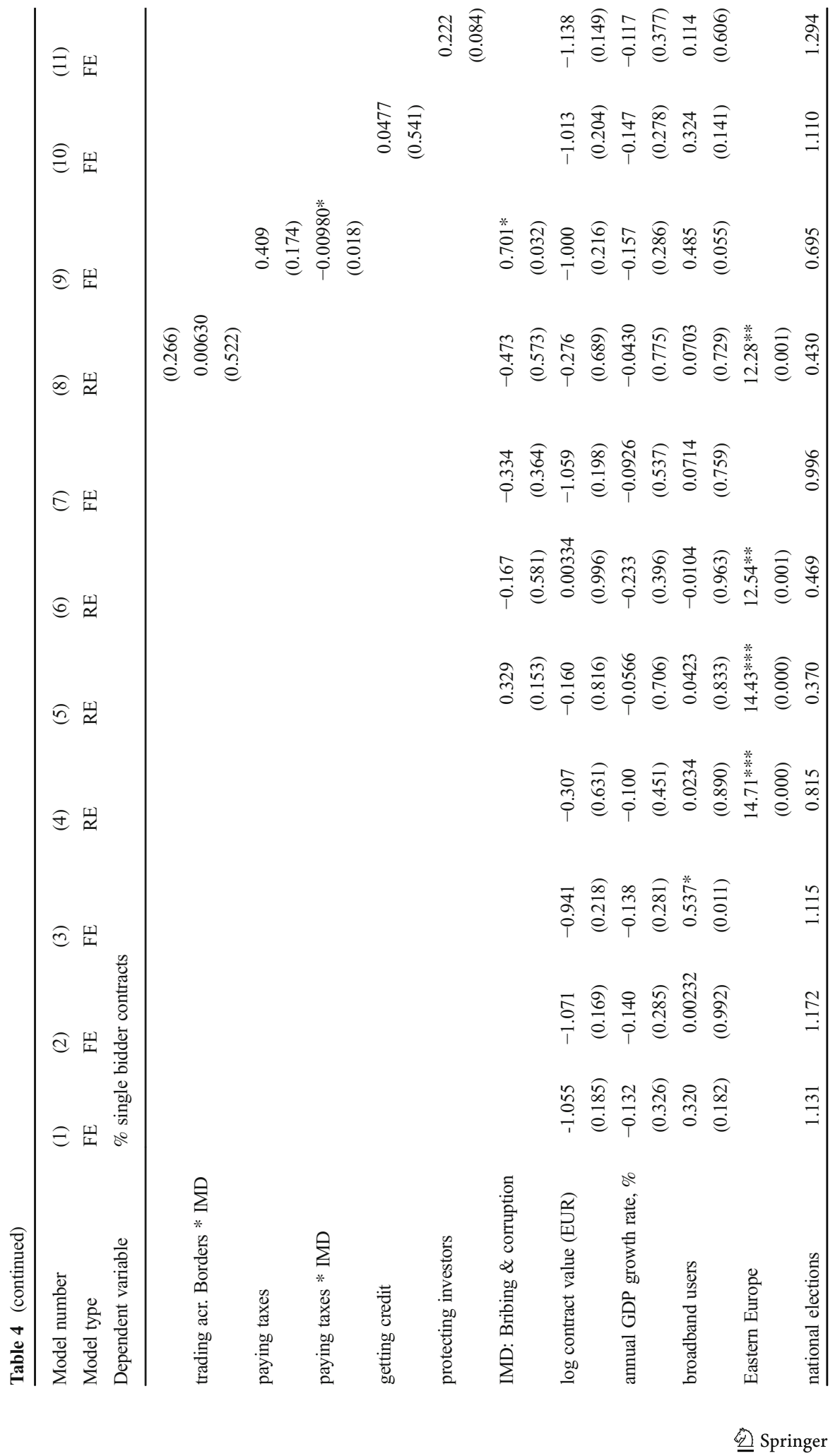




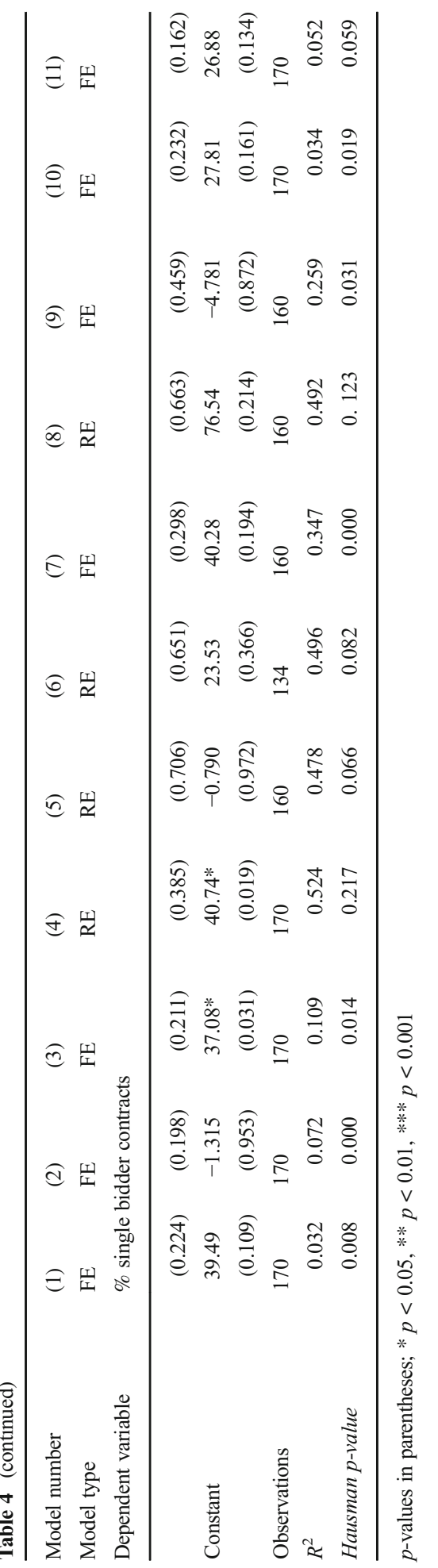


$\mathrm{CRI}$ as outcome). In regulatory areas: registering property, getting electricity, construction permits, and trade, neither direct nor indirect effects of deregulation are significant. Direct effects have been hypothesized as being negligible which is confirmed by regressions, however, indirect effects are not significant suggesting that low-level bribery may not act as an impact channel to curbing government favouritism. This finding may be due to the relatively weak link between deregulation and bribery in these regulatory areas to start with, however, further research is needed. Quite importantly, deregulation of paying taxes has an insignificant direct effect on government favouritism, while it has the expected divergent indirect effect depending on the level of low-level bribery (Fig. 1). When bribery is rampant deregulation leads to lower favouritism while where bribery is rare the opposite effect is estimated in the regressions.

In line with our hypotheses, regulations of private-to-private business interactions have an insignificant effect on petty corruption in our models.

\section{Conclusions and policy consequences}

Using basic country-level panel regression analysis, we find that deregulation has a heterogeneous impact on both low and high level corruption (Table 5). Deregulating the various channels through which governments and businesses interact (e.g. obtaining construction permits) often decreases the perception of bribery and petty corruption however the effects seem to be dependent on the measure used and regulatory area considered. Our findings are less reliable in this respect given the somewhat blurred survey measurement instruments used to measure low-level bribery (e.g. also including bribery linked to obtaining government contracts).

Deregulation is largely ineffective in tackling government favouritism, especially regulations of day-to-day interactions between businesses and governments (Table 5). Most significantly, deregulation facilitating corrupt rent extraction by ruing elites (i.e. business start-up deregulation) facilitates government favouritism, while deregulating regulatory areas constraining elites such as ease of contract enforcement can effectively

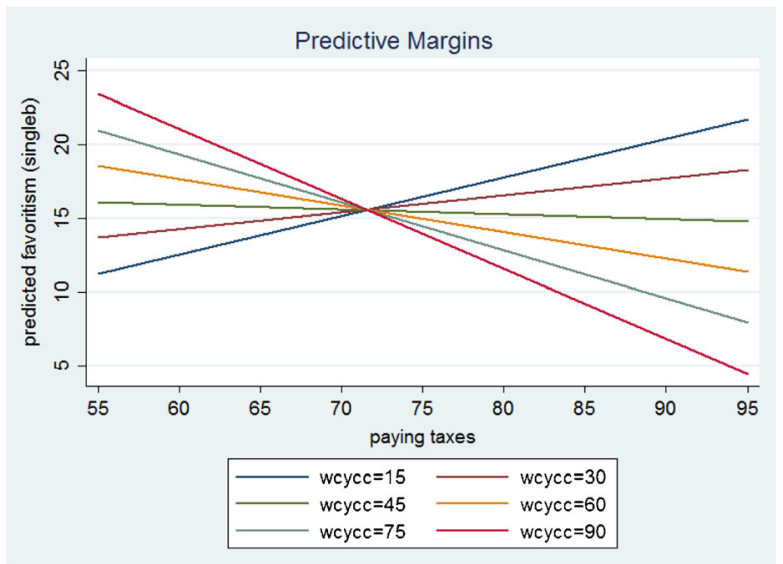

Fig. 1 Predicted relationships between taxpaying regulation and government favouritism (single bidding) mediated by perceptions of bribery (IMD: Bribing \& corruption (wcycc)) 
Table 5 Summary of empirical findings by business regulation and corruption types (relationships in line with hypotheses highlighted in green)

\begin{tabular}{lcc}
\hline $\begin{array}{l}\text { Doing Business } \\
\text { component }\end{array}$ & bribery & favouritism \\
\hline total regulatory burden & $\mathbf{0}$ & $-/ \mathbf{0}$ \\
starting business & $\mathbf{0}$ & + \\
resolving insolvency & $\mathbf{0}$ & - \\
enforcing contracts & $\mathbf{0}$ & - \\
registering property & - & $\mathbf{0}$ \\
getting electricity & - & $\mathbf{0}$ \\
construction permits & - & $\mathbf{0}$ \\
trade & + & $\mathbf{0}$ \\
paying taxes & $\mathbf{0}$ & $+/-$ \\
getting credit & $\mathbf{0}$ & $\mathbf{0}$ \\
protecting investors & $\mathbf{0}$ & $\mathbf{0}$ \\
\hline
\end{tabular}

constrain government favouritism. The effect of deregulating taxpaying is driven by the indirect channel going through the level of bribery to start with, that is where bribery is widespread deregulation seems to lower favouritism, while where bribery is rare deregulation is surprisingly increasing favouritism.

These findings uncovering the heterogeneous relationships between different types of regulation and different types of corruption further refine previous findings in the literature using more disaggregated corruption measures and less detailed data on regulatory burden in different areas [16]. Further research would be needed to test whether these findings using a particular medium to high income country sample in Europe would also hold for a broader country sample.

The causal interpretation of any of these effects needs to be taken with caution due to the limited nature of the time-series cross-country data we use. The identified effects are considerable both economically and politically albeit they are clearly insufficient to move corruption equilibria on their own. Rather they could form part of a powerful and effective anticorruption package, a big-bang approach, as suggested by historical as well as contemporary case studies [47, 48].

Policy consequences are profound and point at a more targeted and contextdependent promotion of the deregulation agenda. First, deregulating day-to-day business-state interactions is most likely only effective in curbing low-level corruption rather than government favouritism. Second, deregulation is not always acting as a curb on corruption, especially on government favouritism. It can also increase the ease of corrupt rent extraction in the case of deregulating business registration. This results suggest that there may be a tension between fighting low versus high level corruption. Third, in some areas such as contract enforcement and registering property, deregulation may effectively combat low as well as high level corruption without detrimental effects on one or the other corruption type. 


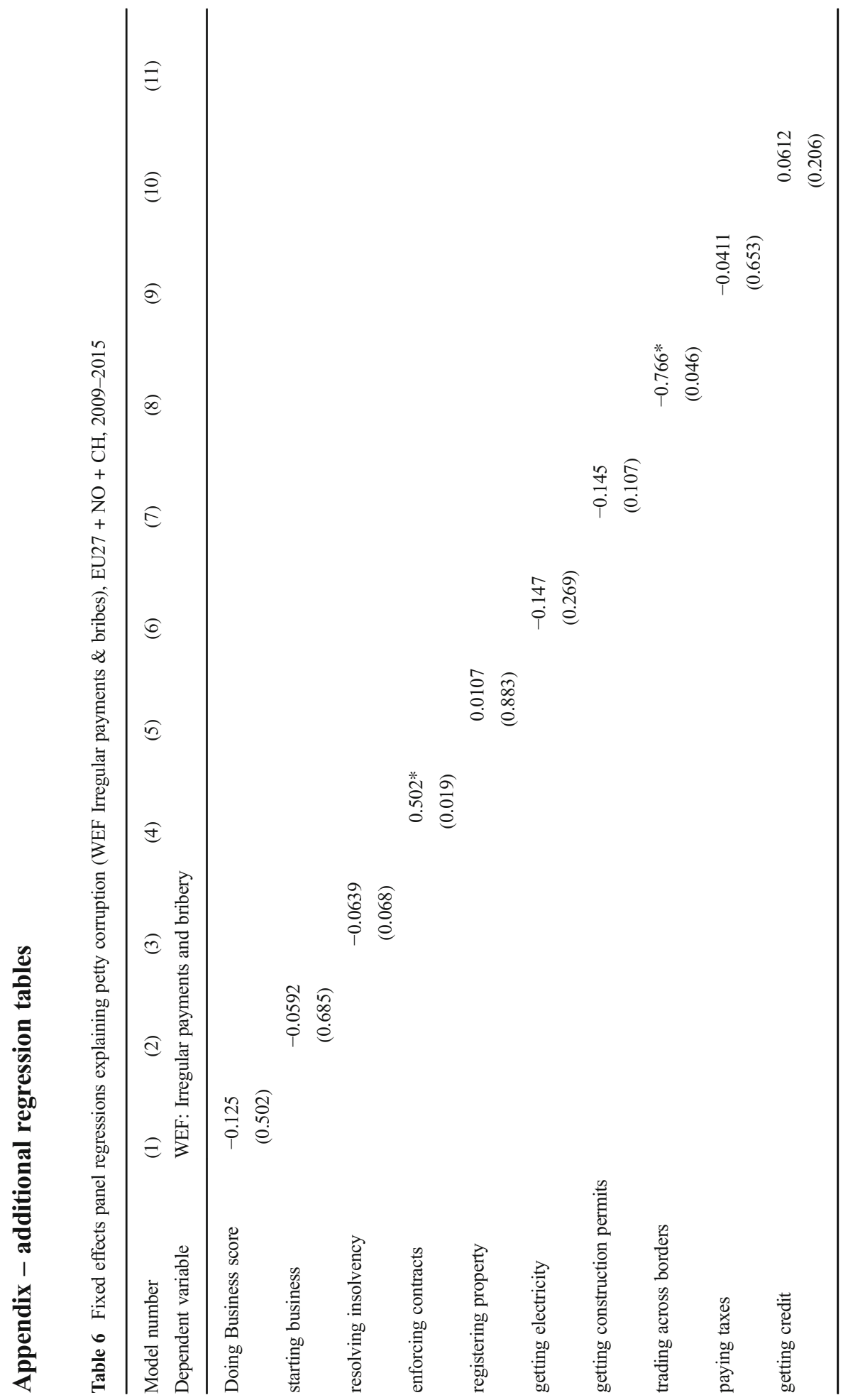




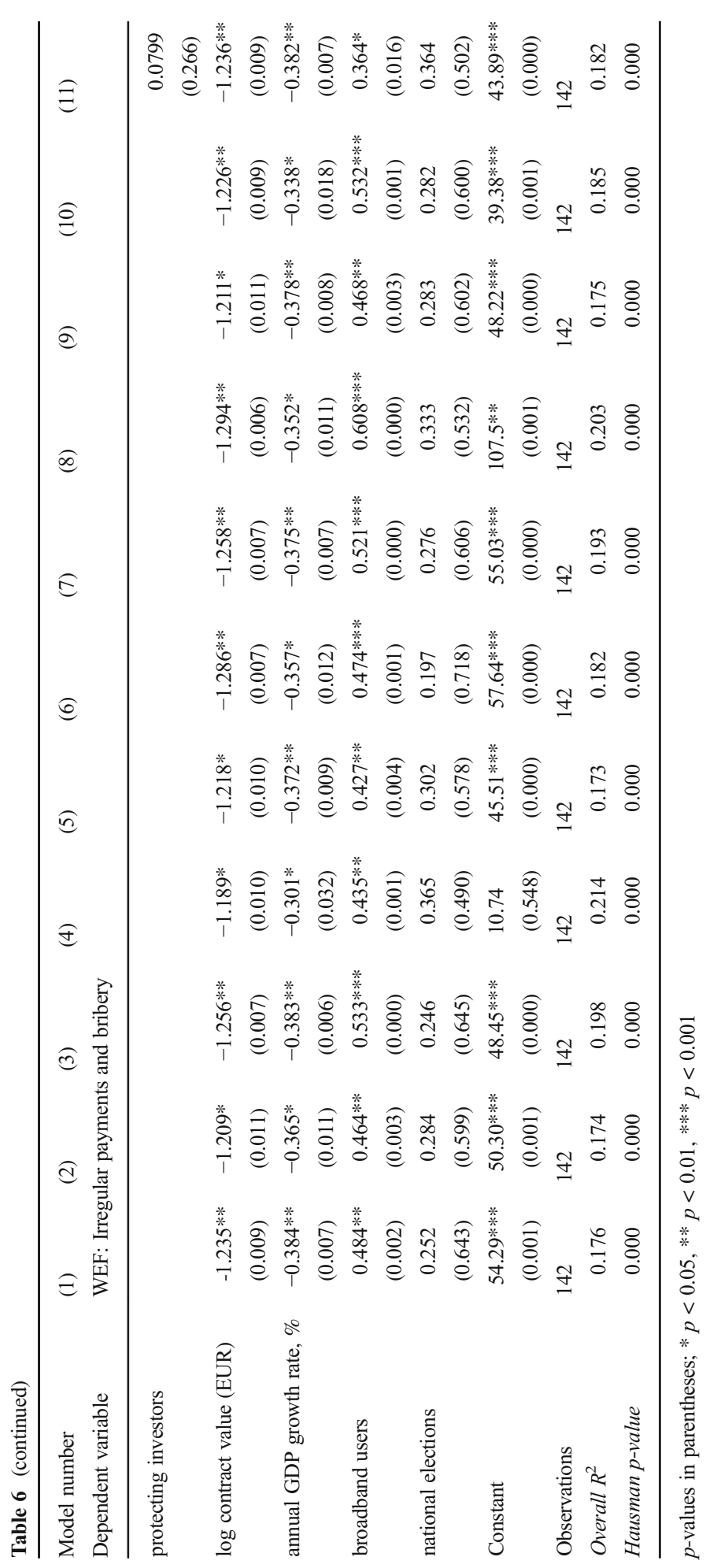




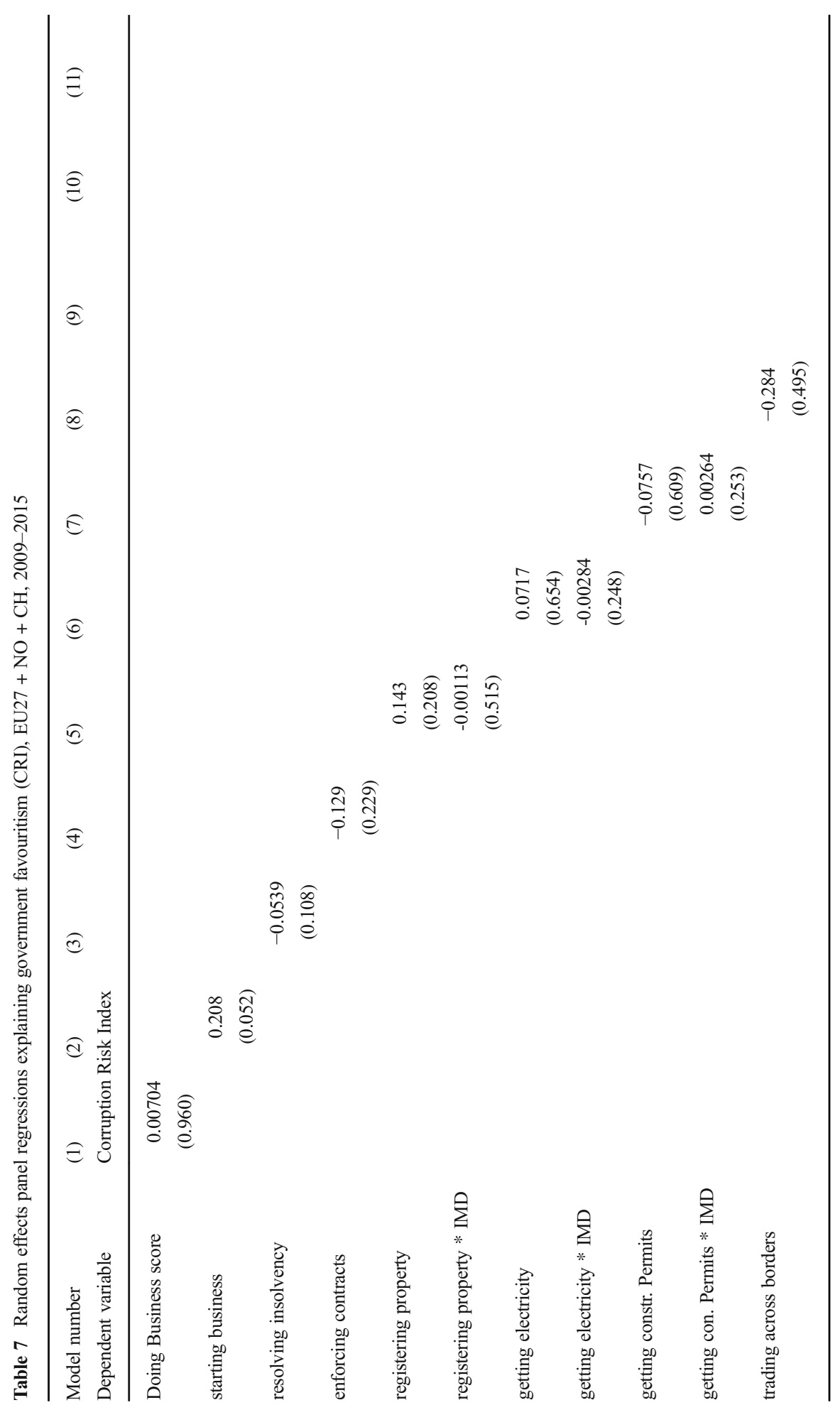




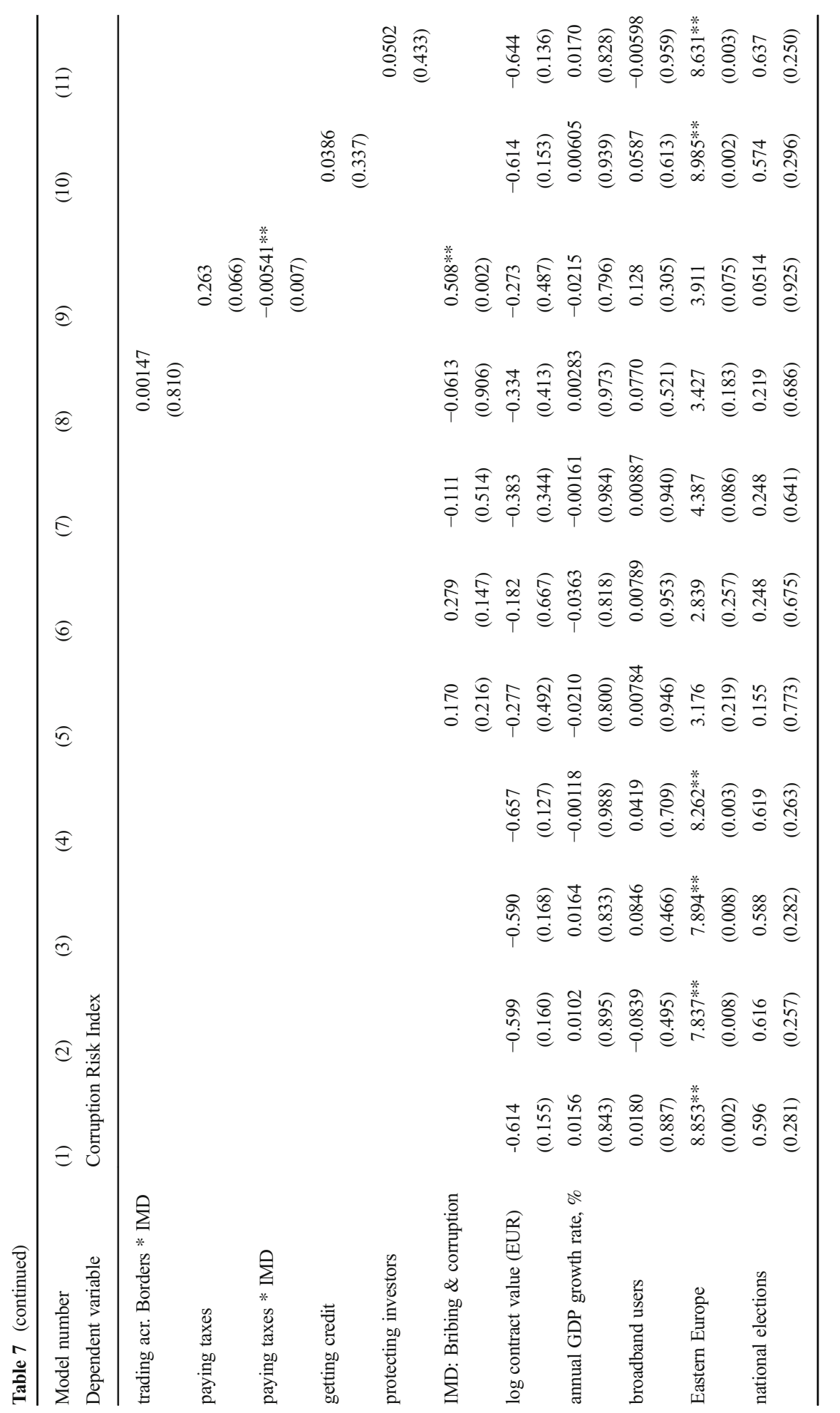




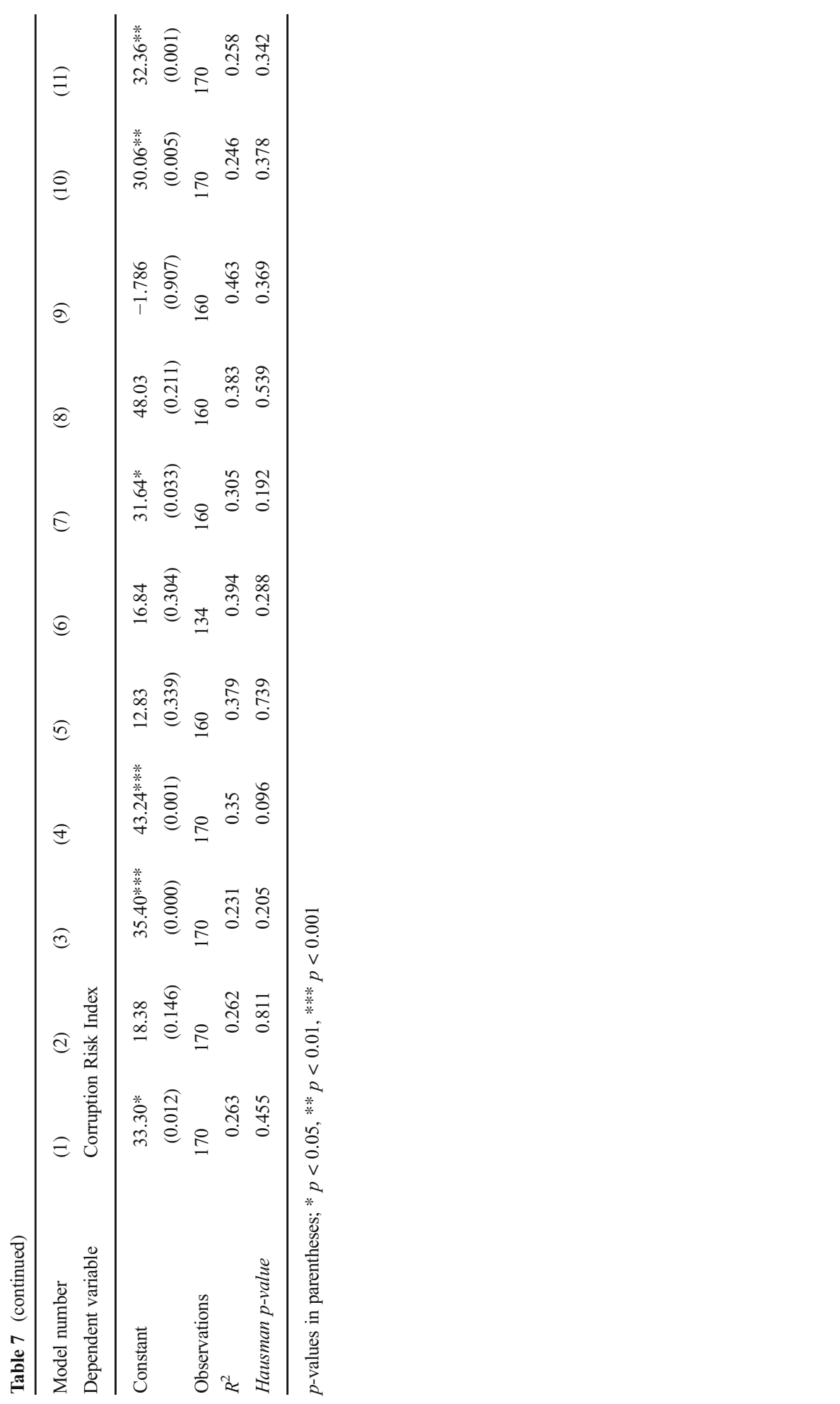


Open Access This article is distributed under the terms of the Creative Commons Attribution 4.0 International License (http://creativecommons.org/licenses/by/4.0/), which permits unrestricted use, distribution, and reproduction in any medium, provided you give appropriate credit to the original author(s) and the source, provide a link to the Creative Commons license, and indicate if changes were made.

\section{References}

1. Mauro, P. (1995). Corruption and growth. Quarterly Journal of Economics, 110(3), 681-712.

2. World Bank. (2016b). Doing Business 2016. Measuring regulatory quality and efficiency. Washington DC: World Bank Publications.

3. Djankov, S. (2009). The regulation of entry : a survey. The World Bank Research Observer, 24(2), 183203.

4. Lambsdorff, J. G. (2006). Causes and consequences of corruption: what do we know from a cross-section of countries? In S. Rose-Ackerman (Ed.), International handbook on the economics of corruption (pp. 351). Cheltenham: Edward Elgar.

5. Treisman, D. (2007). What have we learned about the causes of corruption from ten years of crossNational Empirical Research. Annual Review of Political Science, 10, 211-244.

6. Rose-Ackerman, S. (2015). Are corrupt elites Neccessary for corrupt COuntries? In C. Dahlström \& L. Wangnerud (Eds.), Elites, institutions and the quality of government (pp. 33-48). New York: Palgrave Macmillan.

7. Dávid-Barrett, E., \& Fazekas, M. (2016). Corrupt contracting: Controlling Partisan Favouritism in Public Procurement (ERCAS Working Paper No. 49). Berlin.

8. Johnston, M. (1996). The search for definitions: the vitality of politics and the issue of corruption. International Social Science Journal, 48(149), 321-335.

9. Rose-Ackerman, S. (1978). Corruption: a study in political economy. New York: Academic Press.

10. Rose-Ackerman, S., \& Palifka, B. J. (2016). Corruption and government: Causes, consequences, and reform (2nd ed.). Cambridge: Cambridge University Press.

11. Warren, M. E. (2003). What does corruption mean in a Democracy? American Journal of Political Science, 48(2), 328-343.

12. Mungiu-Pippidi, A. (2006). Corruption: diagnosis and treatment. Journal of Democracy, 17(3), 86-99.

13. North, D. C., Wallis, J. J., \& Weingast, B. R. (2009). Violence and social orders. A conceptual framework for interpreting recorded human history. Cambridge: Cambridge University Press.

14. Rothstein, B., \& Teorell, J. (2008). What is quality of government? A theory of impartial government institutions. Governance, 21(2), 165-190.

15. Duvanova, D. (2014). Economic regulations, red tape, and bureaucratic corruption in post-communist economies. World Development, 59, 298-312.

16. Mungiu-Pippidi, A., \& Dadašov, R. (2016). Measuring control of corruption by a new Index of public integrity. European Journal on Criminal Policy and Research, 22(3), 415-438.

17. Goel, R. K. (2012). Business regulation and taxation: Effects on cross-country corruption. Journal of Economic Policy Reform, 15(3), 223-242.

18. Svensson, J. (2005). Eight questions about corruption. Journal of Economic Perspectives, 19(3), 19-42.

19. Fazekas, M., Cingolani, L., \& Tóth, B. (2016a). A comprehensive review of objective corruption proxies in public procurement: risky actors, transactions, and vehicles of rent extraction. Government Transparency Institute Working Paper Series No. GTI-WP/2016:03, Budapest.

20. Jancsics, D. (2016). Offshoring at home? Domestic use of Shell companies for corruption. Public Integrity, 19(1), 4-21.

21. Lambsdorff, J. G. (2002). Making corrupt deals: contracting in the shadow of the law. Journal of Economic Behavior \& Organization, 48(3), 221-241. doi:10.1016/S0167-2681(01)00217-7.

22. Coviello, D., Moretti, L., Spagnolo, G., \& Valbonesi, P. (2017). Court efficiency and procurement performance. Scandinavian Journal of Economics. doi:10.1111/sjoe.12225full.

23. Grzymala-Busse, A. (2008). Beyond Clientelism : Incumbent state capture and state formation. Comparative Political Studies, 41(4/5), 638-673.

24. Institute for Management Development. (2016). World Competitiveness yearbook. Lausanne: IMD.

25. World Economic Forum. (2010). The global Competitiveness report 2012-2013. Geneva: World Economic Forum. 
26. Fazekas, M., \& Tóth, I. J. (2014). New ways to measure institutionalised grand corruption in public procurement (U4 Brief No. 2014:9). U4 Anti-Corruption Resource Centre, Bergen.

27. World Bank. (2009). Fraud and corruption. Awareness Handbook. Washington DC: World Bank.

28. DG GROWTH (2015). TED structured dataset (2009-2014), tenders electronic daily, supplement to the Official Journal of the European Union. Brussels.

29. European Commission (2014). Public procurement indicators 2012. Brussels.

30. Charron, N., Dahlström, C., Fazekas, M., \& Lapuente, V. (2017). Careers, connections, and corruption risks: investigating the impact of bureaucratic meritocracy on public procurement processes. Journal of Politics, 79(1), 89-104.

31. Fazekas, M., Chvalkovská, J., Skuhrovec, J., Tóth, I. J., \& King, L. P. (2014). Are EU funds a corruption risk? The impact of EU funds on grand corruption in central and Eastern Europe. In A. Mungiu-Pippidi (Ed.), The anticorruption frontline. The ANTICORRP project (Vol. 2, pp. 68-89). Berlin: Barbara Budrich Publishers.

32. Fazekas, M., Tóth, I. J., \& King, L. P. (2016b). An objective corruption risk Index using public procurement data. European Journal of Criminal Policy and Research, 22(3), 369-397.

33. Fazekas, M., Tóth, I. J., \& King, L. P. (2013). Corruption manual for beginners: Inventory of elementary "corruption techniques" in public procurement using the case of Hungary. Working Paper Series No. GTI-WP/2013:01, Government Transparency Institute, Budapest.

34. OECD. (2007). Integrity in public procurement. Good Practice from A to Z. Paris: OECD.

35. Pricewaterhouse Coopers. (2013). Identifying and reducing corruption in public procurement in the EU. Brussels: PricewaterhouseCoopers and Ecorys.

36. Lengwiler, Y., \& Wolfstetter, E. (2006). Corruption in procurement auctions. In N. Dimitri, G. Piga, \& G. Spagnolo (Eds.), Handbook of procurement (pp. 412-429). Cambridge: Cambridge University Press.

37. Chong, E., Klien, M., \& Saussier, S. (2015). The Quality of Governance and the Use of Negotiated Procurement Procedures: Evidence from the European Union (EPPP DP No. 2015-3). Paris.

38. Piga, G. (2011). A fighting chance against corruption in public procurement? In S. Rose-Ackerman \& T. Soreide (Eds.), International handbook on the economics of corruption, volume two (pp. 141-181). Cheltenham: Edward Elgar.

39. Heggstad, K. K., \& Froystad, M. (2011). The basics of integrity in procurement. Bergen: U4 AntiCorruption Resource Centre Chr. Michelsen Institute (CMI).

40. Fazekas, M., \& Kocsis, G. (2015). Uncovering High-Level Corruption: Cross-National Corruption Proxies Using Government Contracting Data. GTI Working Papers No. GTI-WP/2015:02, Budapest.

41. Klemperer, P. (2007). Bidding markets. Journal of Competition Law and Economics, 3(1), 1-47.

42. Tóth, B., Fazekas, M., Czibik, Á., \& Tóth, I. J. (2014). Toolkit for detecting collusive bidding in public procurement. With examples from Hungary. Working Paper Series No. CRCB-WP/2014:02, Budapest: Corruption Research Center Budapest.

43. Shaxson, N., \& Christensen, J. (2014). The finance curse. How oversized financial Centres attack Democracy and corrupt economies. Chesham: Tax Justice Network.

44. Klasnja, M. (2016). Corruption and the incumbency disadvantage: theory and evidence. Journal of Politics, 77(4), 928-942.

45. World Bank (2016a). Distance to frontier and ease of doing business ranking. Washington DC.

46. Fazekas, M., \& Cingolani, L. (2016). Breaking the cycle? How (not) to use political finance regulations to counter public procurement corruption. Working Paper Series No. GTI-WP/2016:01, Budapest.

47. Mungiu-Pippidi, A. (2015). The quest for good governance. How societies develop control of corruption. Cambridge: Cambridge University Press.

48. Rothstein, B. (2011). Anti-corruption: The indirect "big-bang" approach. Review of International Political Economy, 18(2), 228-250. 